Jurnal Visionida, Volume 4 Nomor 1 Juni 2018

\title{
ANALISIS PENGARUH CUSTOMER EXPERIENCE TERHADAP MINAT BERKUNJUNG KEMBALI (REVISIT INTENTION) PADA DESTINASI WISATA KOTA BOGOR
}

\section{THE ANALYSIS EFFECT CUSTOMER EXPERIENCE ON REVISIT INTENTION IN DESTINATION THE TOURIST DESTINATIONS IN THE CITY OF BOGOR}

\author{
Hardiansyah $^{1)}$; Erni Yuningsih ${ }^{2)}$ \\ Program Management Studies Faculty, University of Djuanda Bogor \\ Email : hardiansyah@unida.ac.id
}

\begin{abstract}
The purpose of study was to determine: 1) description of customer experience to the tourist destinations in the city of Bogor, 2) description revisit intention to tourist destinations in the city of Bogor, 3) the impact of customer experience to the revisit intention to the tourist destinations of Bogor. Data were collected through questionnaires, in-depth interviews and observations. The method of analysis using descriptive analysis, multiple regression, $F$ test and $t$ - test. Simultaneousaly variable comfort, educationalal, hedonic, novelty, safety and beauty have a positive and significant effect on the revisit intention to the tourist destinations city of Bogor. While partialy comfort, hedonic, novelty, safety and beauty have a positive and significant effect to the revisit intention, while the educationalal factor has no effect.
\end{abstract}

Keywords: Customer Experience, Revisit Intention

\begin{abstract}
ABSTRAK
Tujuan Penelitian adalah untuk mengetahui: 1) gambaran customer experience pada destinasi wisata kota Bogor, 2) gambaran revisit intention terhadap destinasi wisata kota Bogor, 3) pengaruh customer experience terhadap minat berkunjung kembali (revisit intention) pada destinasi wisata kota Bogor. Data dikumpulkan melalui kuesioner, wawancara mendalam dan observasi. Metode analisis menggunakan analisis deskriptif, regresi berganda, uji $\mathrm{F}$ dan uji-t. Secara simultan variabel comfort, educational, hedonic, novelty, safety dan beauty memiliki pengaruh positif dan signifikan terhadap minat berkunjung kembali pada destinasi wisata kota Bogor. Hasil pengujian secara parsial (uji-t) menyimpulkan bahwa faktor comfort, hedonic, novelty, safety dan beauty berpengaruh positif dan signifikan terhadap minat berkunjung kembali (revisit intention), sedangkan faktor educational tidak berpengaruh.
\end{abstract}

Kata Kunci : Customer Experience, Minat Berkunjung Kembali 


\section{PENDAHULUAN}

Indonesia adalah negara yang memiliki banyak kepulauan, kaya akan berbagai macam suku, agama, budaya, bahasa, flora (tumbuhan) dan fauna (hewan). Banyaknya kekayaan yang dimiliki negara Indonesia berpeluang besar untuk dikembangkan pada sektor pariwisata. Sumberdaya dan modal tersebut perlu dimanfaatkan secara optimal melalui kepariwisataan.

Industri pariwisata tidak sedikit memberikan peran penting bagi perekonomian Indonesia karena memberikan masukan berupa pendapatan daerah dan juga dapat menciptakan lapangan kerja. Menurut Yoeti (2008:43) industri pariwisata memberikan peran penting bagi perkembangan budaya karena dengan adanya obyek wisata maka dapat memperkenalkan keragaman berbagai budaya seperti kesenian tradisional, upacaraupacara agama dan adat istiadat, yang akan menarik perhatian wisatawan domestik maupun mancanegara.

Adapun tujuan dari penyelenggaraan pariwisata yaitu; 1) meningkatkan pendapatan nasional; 2) mendorong pembangunan daerah; 3) memperluas lapangan pekerjaan serta memeratakan kesempatan berusaha;4) memperkenalkan pesona wisata Indonesia; 5) menumbuhkan rasa cinta tanah air dan mempererat tali persahabatan berbagai bangsa.

Pariwisata kini sudah menjadi bagian hidup masyarakat dunia bahkan dikalangan berpenghasilan menengah ke atas, berwisata merupakan suatu kebutuhan pokok. Berdasarkan data Kementerian Pariwisata tahun 2015, sektor pariwisata menghasilkan devisa sebesar 11,9 miliar dollar US. Sebanyak 12,6 juta orang bekerja pada sektor pariwisata (Kementrian Pariwisata, 2016). Peringkat daya saing Indonesia, menurut World Economi Forum (WEF) juga membaik, dari peringkat ke-70 menjadi peringkat ke-20 dari 141 negara. Hal ini ditunjukkan dengan data perkembangan perjalanan wisatawan nusantara ke berbagai tempat wisata diseluruh Indonesia (Kompas,12-06-2016). Berikut ini pertumbuhan perjalanan wisatawan nusantara dari tahun 2011-2015 dapat dilihat pada gambar 1 dibawah ini :

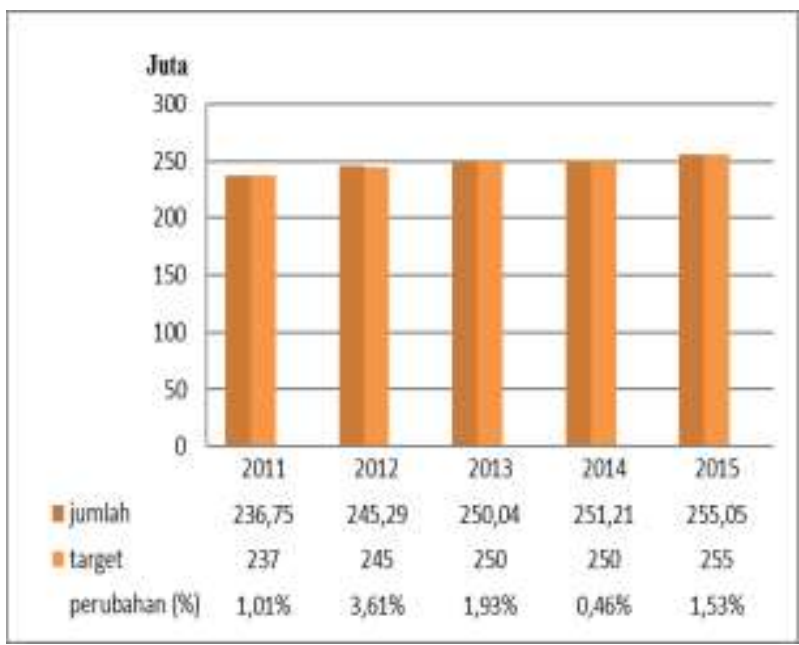

Gambar 1. Pertumbuhan Wisatawan Nusantara Sumber : Data Kementrian Pariwisata, 2016

Berdasarkan gambar 1 pertumbuhan wisatawan nusantara setiap tahunnya sesuai dengan target yang telah ditetapkan. Tingkat pertumbuhan paling tinggi sebesar 3,61\% terjadi pada tahun 2012, walaupun terjadi penurunan pada tahun-tahun berikutnya tapi sudah mencapai target yang telah ditetapkan. Dari data gambar 1 di atas memperlihatkan bahwa potensi kepariwisataan Indonesia mampu menjadi salah satu sumber devisa bagi negara.

Minat/niat berkunjung kembali disebut dengan revisit intention, didefinisikan sebagai kemungkinan wisatawan untuk mengulangi aktifitas datang kembali ke suatu tempat destinasi (Baker dan Crompton dalam ChungHslen Lin (2012:1-28). Menurut Meyer and Schwager dalam Rageh et al (2013:126), berkaitan dengan hal tersebut, apabila penawaran destinasi tersebut menarik, maka akan mendorong wisatawan untuk datang kembali ke objek wisata tersebut, karena potensi kepariwisataan merupakan satu diantara banyak faktor yang menyebabkan 
wisatawan berkunjung ke suatu tempat wisata. Jika wisatawan merasakan suatu kepuasan terhadap objek wisata maka mereka akan mengulangi lagi kunjungannya ke tempat objek wisata tersebut (revisit intention), dan kemudian akan merekomendasikannya kepada yang lain.

Bogor merupakan kota di propinsi Jawa Barat yang mempunyai potensi wisata cukup potensial untuk dikembangkan. Banyak sekali tempat wisata menarik, baik wisata alam, pendidikan, hiburan, kuliner, belanja, cendramata dan hotel. seperti Kebun Raya, Batu Tulis, Situ Gede, The Jungle, Marcopolo, Taman Sempur, Taman Kencana, Bogor Trade Mall, Botani Square dan masih banyak lagi tempat wisata lainnya. Secara administratif dan geografis, kota Bogor memiliki posisi yang strategis karena dekat dengan Jakarta sebagai ibu kota negara. Berikut data perkembangan kunjungan wisatawan kota Bogor dari tahun 2011-2015 adalah :

\section{Tabel 1. Data Perkembangan Kunjungan} Wisatawan

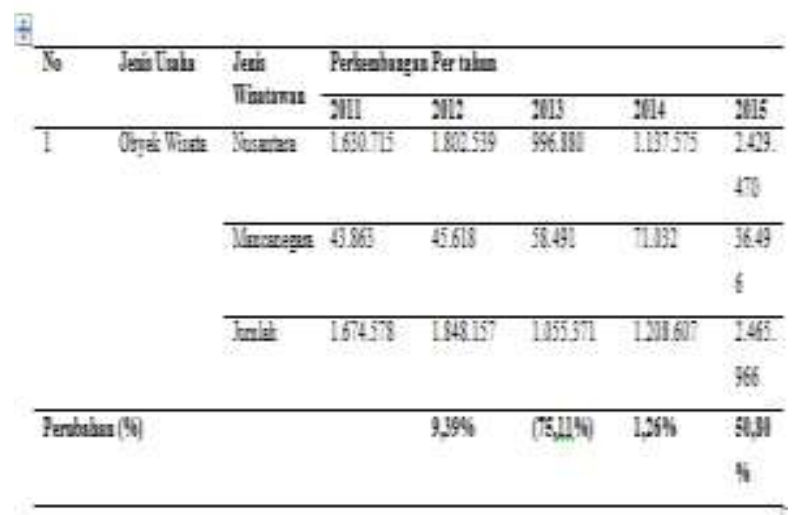

Sumber : Dinas Kebudayaan Pariwisata Kota Bogor, 2016.

Berdasarkan data tersebut terlihat perkembangan kunjungan wisatawan baik objek wisata maupun akomodasi mengalami perkembangan yang tidak signifikan, bahkan pada tahun 2013 terjadi penurunan sebesar $75,11 \%$. Penurunan jumlah wisatawan diduga disebabkan karena banyak tempat wisata yang semakin beragam dan menarik sehingga wisatawan cenderung melakukan kunjungan keberbagai destinasi lain untuk merasakan pengalaman baru, juga banyaknya destinasi lain diluar kota Bogor yang menawarkan inovasi produk yang beragam.

Berdasarkan permasalahan di atas penting untuk melakukan penelitian mengenai pengaruh dari customer experience terhadap minat berkunjung kembali pada destinasi wisata kota Bogor, sehingga objek wisata kota Bogor bisa bersaing dan minat berkunjung kembali dari para wisatawan dapat ditingkatkan.

\section{MATERI DAN METODE}

\section{Customer Experience}

Menurut Walter et al, (2010:238) pengalaman konsumen (customer experience) didefinisikan sebagai pengalaman yang didapatkan konsumen secara langsung ataupun tidak langsung mengenai proses pelayanan, perusahaan, fasilitas serta interaksi dengan konsumen lainnya. Berikutnya menurut Schmitt (1999:142), berpendapat pengalaman adalah peristiwa atau kejadian-kejadian yang memiliki kesan pribadi, yang terjadi sebagai tanggapan atau hasil dari suatu rangsangan (stimulus).

\section{Dimensi Customer Experience}

Terdapat delapan dimensi dari customer experience, penulis hanya akan meneliti enam dimensi yang berkaitan dengan objek penelitian. Keenam dimensi tersebut adalah comfort, educational, hedonic, Novelty, beauty, and safety dengan penjelasan sebagai berikut:

1. Comfort (kenyamanan) merupakan kondisi perasaan seseorang yang merasakan suatu kenyamanan berdasarkan persepsi secara individual. Persepsi seseorang terhadap kenyamanan berbeda-beda tergantung dari kondisi perasaan dari individu tersebut yang mengalami situasi tersebut. 
2. Educational (edukasi) merupakan proses pembelajaran baik formal atau non formal yang diperoleh melalui suatu kejadian ataupun peristiwa yang telah dialami baik secara individual atau bersama-sama.

3. Hedonic (kesenangan) adalah sebagai suatu sikap introspektif hidup berdasarkan mengambil kesenangan diri sendiri dan kenikmatan orang lain, tanpa merugikan diri sendiri atau orang lain. Dimensi hedonis melambangkan semangat, kenikmatan dan mudah dikenang.

4. Novelty (hal baru) adalah unsur kebaruan atau temuan dari sebuah observasi dan penelitian.

5. Safety (keamanan) adalah suatu keadaan bebas dari bahaya.

6. Beauty (Keindahan) adalah enak dipandang atau dilihat, bagus, indah atau elok.

\section{Minat Kunjung Kembali (Revisit Intention)}

Menurut Umar (2003:12), minat kunjung kembali/ulang merupakan suatu perilaku yang muncul sebagai respon terhadap objek yang menunjukkan adanya suatu keinginan untuk melakukan pembelian kembali. Sedangkan menurut Baker dan Crompton dalam ChungHslen Lin (2012:1-22) menjelaskan bahwa revisit intention adalah mengulang kembali aktifitas untuk berkunjung ulang ke suatu destinasi.

\section{Dimensi Minat Berkunjung Kembali}

Dimensi yang dikemukakan oleh Baker dalam Crompton dalam Chung-Hslen Lin (2012:1-28) terdapat dua dimensi minat berkunjung krmbali, yaitu :

a) Intention to recommend yaitu adanya suatu keinginan untuk memberikan rekomendasi kepada pihak lain

b) Intention to revisit yaitu keinginan untuk datang berkunjung kembali .

\section{Desain Penelitian}

Metode penelitian dalam penelitian ini menggunakan penelitian deskriptif dan verifikatif. Adapun pengertian deskriptif menurut Sugiyono (2013:147) merupakan penelitian yang berkaitan dengan pertanyaan terhadap keberadaan variabel mandiri, baik hanya satu variabel atau lebih. Sedangkan penelitian verifikatif adalah penelitian terhadap suatu populasi atau sampel yang bertujuan untuk menguji hipotesis yang sudah ditetapkan sebelumnya (Sugiono,2013:147).

Variabel yang akan analisis terdiri dari variabel X (variabel bebas) yaitu customer experience yang memiliki sub variabel yaitu comport $\left(\mathrm{X}_{1}\right)$, education $\left(\mathrm{X}_{2}\right)$, hedonic $\left(\mathrm{X}_{3}\right)$, safety $\left(\mathrm{X}_{4}\right)$, novelty $\left(\mathrm{X}_{5}\right)$ dan beauty $\left(\mathrm{X}_{6}\right)$ sedangkan variabel $\mathrm{Y}$ (variabel terikat) adalah minat berkunjung kembali

Data yang digunakan dalam penelitian ini adalah data primer dan data sekunder. Data primer diperoleh melalui pengamatan terhadap objek penelitian dengan menyebarkan kuesioner kepada responden yang terpilih menjadi sampel, sedangkan data sekunder diperoleh dari dokumentasi perusahaan, berbagai literatur, penelitian terdahulu yang relevan dengan penelitian yang dilakukan dan data-data lain yang berhubungan dengan penelitian ini .

\section{Metode Penarikan Sampel}

Menurut Gay dan Diehl, Roscoe (1992:126) untuk penelitian deskriptif ukuran sampel lebih dari 30 dan kurang dari 500 adalah tepat untuk kebanyakan penelitian. Untuk memenuhi syarat tersebut maka diambil 100 sampel dengan alasan subyektif (judgement) untuk penelitian ini.

Penarikan sampel yang terpilih menggunakan metode sampel acak yang distratakan secara banding. Hal ini dilakukan karena obyek penelitian relatif bersifat homogen (Nazir, 1983:360). Untuk mengetahui ukuran sampel wisatawan destinasi pariwisata kota Bogor dilakukan secara proporsional random sampling, dengan jumlah sampel yang dijadikan penelitian adalah 100 responden. 


\section{Teknik Pengujian Instrumen}

Setelah indikator dikembangkan berdasarkan konsep teoritis variabel, maka instrument dari penelitian (kuesioner) dilakukan uji coba kepada populasi yang jumlah nya lebih kecil untuk mewakili karakteristik dari populasi yang sebenarnya. Uji yang dilakukan adalah uji validitas dan reliabilitas. Uji validitas dan reliabilitas untuk setiap item pernyataan atau pertanyaan dalam kuesioner menunjukkan hasil bahwa instrument penelitian dinyatakan valid dan reliabel.

\section{Metode Analisis Data}

Metode untuk menganalisis data menggunakan statistik deskriptif. Metode ini digunakan untuk mengetahui karakteristik responden yang diukur dari sejumlah indikator-indikator yang ditanyakan melalui kuesioner. Data yang terkumpul melalui kuesioner terlebih dahulu dilakukan tabulasi dengan memberikan nilai sesuai dengan penilaian yang sudah ditetapkan..Pembobotan skor skala pada kuesioner menggunakan skala Likert sehingga menghasilkan nilai frekuensi dan nilai rata-rata (mean) dari setiap indikator yang ditanyakan. Teknik analisis data menggunakan regresi linier berganda, koefisien determinasi, koefisien korelasi dan pengujian asumsi klasik.

\section{HASIL DAN PEMBAHASAN}

Responden yang dijadikan sampel penelitian adalah wisatawan yang sedang berkunjung ke tempat-tempat wisata di kota Bogor. Responden yang diambil sebanyak 100 sampel yang terbagi di empat lokasi tempat wisata yaitu kebun Raya Bogor, The Jungle Waterpark, The Jungle Fest dan Marcopolo. Berikut adalah rekapitulasi dari tanggapan wisatawan terhadap Customer Experience pada destinasi wisata di kota Bogor, adalah :

Tabel 2. Rekapitulasi Tanggapan Responden Terhadap Customer Experience Pada Destinasi Wisata Di Kota Bogor

\begin{tabular}{|c|c|c|c|}
\hline No & Sub Variabel & $\begin{array}{l}\text { Relsapitulasi } \\
\text { T anggap an }\end{array}$ & Intrepretasi \\
\hline 1 & Combart & 3,94 & $\begin{array}{l}\text { Wisatawan mendapatkan pengalaman yang baik terhadap } \\
\text { kenyamaman tempat wisata yang berlaitan dengan tempat } \\
\text { wisata yamg mudah dijangkau, tempat wisata yang lvas dan } \\
\text { bersih termasuk pelayanan yang ramah dari para pemandu } \\
\text { wisata sehing ga membuat pengguna jasa wisata merasa } \\
\text { tenang tentram saat berlanjung ke tempat-tempat wisata di } \\
\text { kota Bogo. }\end{array}$ \\
\hline \multirow[t]{2}{*}{2} & \multirow[t]{2}{*}{ Educational } & \multirow[t]{2}{*}{3,74} & Pada umummya tempat-tempat wisata kota Bogor \\
\hline & & & $\begin{array}{l}\text { memberitan edukasi yang baik terhadap wisatawan } \\
\text { sehing ga menambah pengalaman dan pengetamuan kepada } \\
\text { wisatawan. }\end{array}$ \\
\hline 3 & Hedoric & 3,75 & $\begin{array}{l}\text { Destinasi wisata kota Bogor mampu memberikan } \\
\text { kesenangan sehingga memberikan pengalaman yang baik } \\
\text { dan berkean bagi wisatawan. hal ini membuat tempat } \\
\text { wisata mudah dikenang, menciptakan semangat dan mampu } \\
\text { memuaskan rohani dan jasmani. }\end{array}$ \\
\hline 4 & Novelty & 3,93 & $\begin{array}{l}\text { Wisatawan yang berkanjung pada ummmmya mendapatkan } \\
\text { pengalaman, petwalangan dan sensasi yang baru, larena } \\
\text { tempat wisata di kota } B \text { og or selalv memnjuklan kebaruan } \\
\text { produk wisata sehingga berbeda dari produk wisata yang } \\
\text { sudah ada. }\end{array}$ \\
\hline 5 & Saferty & 4,00 & $\begin{array}{l}\text { Tempat wisata kota Bogor memiliki keamanan yang baik } \\
\text { seperti adarya tim leselamatan, pengawas wahana dan } \\
\text { klinik sehingga memberikan kesan aman saat berkanjung. }\end{array}$ \\
\hline 6 & Beauty & 4,13 & $\begin{array}{l}\text { Pada ummmrya destinasi wisata loota Bogor memiliki } \\
\text { kel bihan keindahan panorama alam, sehingga memberikan } \\
\text { pengalaman yang berkesan terhadap wisatawan }\end{array}$ \\
\hline
\end{tabular}

Sumber : Data Diolah, 2017 
Tabel 2 memperlihatkan bahwa untuk sub variabel dari customer experience dengan penilaian tertinggi adalah variabel beauty, dengan rata-rata penilaian 4,13 . Hal tersebut memperlihatkan bahwa pada umumnya destinasi wisata di kota Bogor mempunyai panorama keindahan alam maupun objek wisata yang dapat memberikan pengalaman berkesan kepada wisatawan. Panorama keindahan alam kota Bogor didukung juga oleh rangkaian pegunungan seperti Gunung Salak dan Gunung Gede, sehingga kota Bogor juga memiliki julukan sebagai kota BERIMAN (Bogor sebagai kota Indah, sejuk dan nyaman). Intrepretasi terendah adalah sub variabel education dengan rata-rata penilaian 3,74. Hal ini dikarenakan pada umumnya alasan wisatawan berwisata adalah untuk memperoleh kesenangan, rekreasi dan menghilangkan kepenatan dan kebosanan karena aktivitas rutin.

Tabel 3. Rekapitulasi Tanggapan Responden Terhadap Minat Berkunjung Kembali (Revisit Intention)

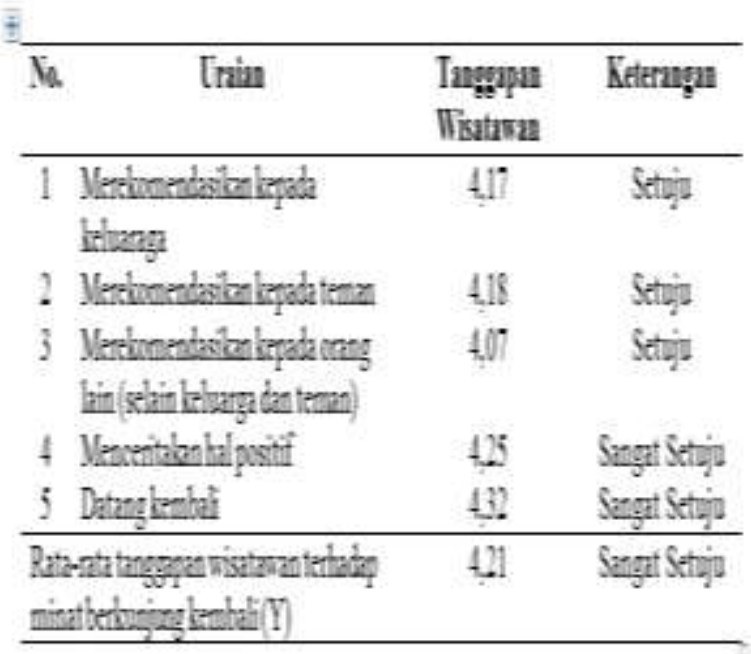

Sumber : Data Diolah, 2017

Berdasarkan tabel 3 hasil dari rekapitulasi menyatakan rata-rata rekapitulasi tanggapan wisatawan yang mendorong minat berkunjung kembali adalah 4,21. Angka penafsiran tertinggi sebesar 4,32 dengan interpretasi datang kembali pada destinasi wisata kota Bogor, sedangkan yang terendah sebesar 4,07 dengan interpretasi merekomendasikan kepada pihak lain (selain keluarga dan teman) tentang destinasi wisata kota Bogor.

\section{Persamaan Regresi Berganda}

Bentuk persamaan dihitung dengan menggunakan regresi linier berganda. Adapun persamaan berikut adalah untuk menunjukkan adanya pengaruh dari customer experience terhadap minat untuk datang berkunjung kembali (revisit intention) ke destinasi pariwisata kota Bogor. Adapun hasil perhitungan bentuk hubungan fungsional dengan menggunakan regresi berganda diperoleh hasil pada tabel 4 berikut ini:

Tabel 4. Hasil Analisis Regresi

\begin{tabular}{|c|c|c|c|c|c|}
\hline Variabel & B & Beta & $\mathrm{I}$ & Sigt & Keterangan \\
\hline Konstanta & & 6.719 & 2563 & 0.012 & berpengaruh \\
\hline Confort $(x)$ & 0.234 & 0.335 & 2.674 & 0.009 & berpengaruh \\
\hline Education $(x 2)$ & -0.096 & -0.170 & -1.134 & 0.260 & tidak terpenganh \\
\hline Hedonic [X] & 0.229 & 0.398 & 2788 & 0.006 & berpengaruh \\
\hline Novelty $(X A)$ & 0.240 & 0.539 & 2345 & 0.021 & berpengaruh \\
\hline Safety $|\times 5|$ & 0.109 & 0.316 & 2227 & 0.028 & berpengaruh \\
\hline Beauty (x6) & 0.174 & 0.375 & 2.157 & 0.33 & berpengaruh \\
\hline T-tabel & 1.98 & & & & \\
\hline R & 0.773 & & & & \\
\hline R.Square & 0.59 & & & & \\
\hline Adjusted R Square & 0.598 & & & & \\
\hline Fhitung & 23.009 & & & & \\
\hline Sig. $F$ & 0.000 & & & & \\
\hline F-tabel & 231 & & & & \\
\hline
\end{tabular}

Sumber : Data Primer, 2017 (Diolah)

Model persamaan regresi dengan model taksiran sebagai berikut:

$Y=6,719+0,335 X_{1}-0,170 X_{2}+0,398 X_{3}+$ $0,539 X_{4}+0,316 X_{5}+0,375 X_{6}+\varepsilon$

Hasil analisis tersebut dapat diinterprestasikan, konstanta (a) sebesar 6,719 artinya pada saat comfort, education, hedonic, novelty, safety dan beauty $\left(\mathrm{X}_{1}, \mathrm{X}_{2}, \mathrm{X}_{3}, \mathrm{X}_{4}, \mathrm{X}_{5}\right.$ dan $\mathrm{X}_{6}=0$ ) maka minat untuk berkunjung kembali ke destinasi wisata kota Bogor sebesar 6,719, koefisien regresi comfort $\left(\mathrm{X}_{1}\right)=$ 0,335 berarti dengan semakin tinggi tingkat 
kenyamanan suatu destinasi wisata maka semakin tinggi minat wisatawan untuk datang berkunjung kembali, koefisien regresi education $\left(\mathrm{X}_{2}\right)=-0,170$ berarti dengan semakin tinggi nilai edukasi yang diberikan oleh destinasi wisata maka semakin kurangnya minat wisatawan untuk datang berkunjung kembali, koefisien regresi hedonic $\left(X_{3}\right)=0,398$ berarti dengan semakin tinggi tingkat kesenangan suatu destinasi wisata maka semakin tinggi minat wisatawan untuk datang berkunjung kembali, koefisien regresi novelty $\left(\mathrm{X}_{4}\right)=0,539$ berarti dengan semakin tinggi kebaruan suatu destinasi wisata maka semakin tinggi minat wisatawan untuk datang berkunjung kembali, koefisien regresi safety $\left(X_{5}\right)=0,316$ berarti dengan semakin tinggi tingkat keamanan suatu destinasi wisata maka semakin tinggi minat wisatawan untuk datang berkunjung kembali, koefisien regresi beauty $\left(\mathrm{X}_{6}\right)=0,375$ berarti dengan semakin tingginya tingkat keindahan suatu destinasi wisata maka semakin tinggi pula minat wisatawan untuk datang berkunjung kembali.

Berdasarkan tabel tersebut dapat diketahui nilai $\mathrm{R}$ adalah 0,773 yang berada pada kategori kuat $(0,601-0,800)$ (Sugiyono, 2014), hal tersebut menunjukkan adanya hubungan antara variabel comfort $\left(\mathrm{X}_{1}\right)$, education $\left(\mathrm{X}_{2}\right)$, hedonic $\left(\mathrm{X}_{3}\right)$, novelty $\left(\mathrm{X}_{4}\right)$, safety $\left(\mathrm{X}_{5}\right)$ dan beauty $\left(\mathrm{X}_{6}\right)$ dengan variabel minat berkunjung kembali (Y) ke tempat destinasi wisata kota Bogor mempunyai hubungan yang kuat.

\section{Koefisien Determinasi}

Koefisien determinasi bertujuan untuk mengetahui seberapa besar jumlah persentase sumbangan pengaruh dari variabel $\mathrm{X}$ secara bersama-sama (serentak) terhadap variabel Y. Berdasarkan tabel 4 tersebut juga dapat diketahui bahwa $R$ Square sebesar 0,598 atau $59,8 \%$. Hal tersebut menunjukkan bahwa persentase sumbangan pengaruh sub variabel $\mathrm{X}$ (Comfort $\left(\mathrm{X}_{1}\right)$, Education $\left(\mathrm{X}_{2}\right)$, Hedonic $\left(\mathrm{X}_{3}\right)$, Novelty $\left(\mathrm{X}_{4}\right)$, Safety $\left(\mathrm{X}_{5}\right)$, dan Beauty $\left(\mathrm{X}_{6}\right)$ terhadap variabel $\mathrm{Y}$ (minat kunjung kembali) adalah sebesar 59,8\%. Besarnya pengaruh faktor-faktor lain di luar model dan eror yang tidak diteliti sebesar 40,2\%.

\section{Hasil Pengujian Hipotesis}

Hipotesis penelitian di uji dengan statistik Uji F, hasil diperoleh melalui tabel perhitungan analisis varians (Anova). Berdasarkan hasil anova nilai $F_{\text {hitung }}$ sebesar 23,009 dan nilai $F_{\text {tabel }}$ untuk $\alpha=0,05$ dengan derajat kebebasan $\mathrm{V}_{1}=6-1=5$ dan $\mathrm{V}_{2}=100-6$ 1=93 sebesar 2,31 bisa dilihat bahwa Fhitung nilainya lebih besar dari nilai Ftabel $(23,009>2,31)$ maka dapat disimpulkan $\mathrm{H}_{0}$ ditolak dan Ha diterima artinya dengan tingkat kepercayaan $95 \%$ variabel X ( comfort, education, hedonic, novelty, safety dan beauty) mempunyai pengaruh positif dan signifikan secara simultan (bersama-sama) terhadap variabel Y (minat berkunjung kembali).

Uji $\mathrm{t}$ dihitung dengan membandingkan $t_{\text {hitung }}$ dan $t_{\text {tabel. }}$. Jika $t_{\text {hitung }}$ lebih besar nilainya dari nilai $t_{\text {tabel }}\left(t_{\text {hitung }}>t_{\text {tabel }}\right)$ maka menunjukkan bahwa variabel $\mathrm{X}$ memiliki pengaruh secara parsial terhadap variabel Y.

Dilihat dari tabel 4 diatas diperoleh hasil bahwa variabel hedonic (kesenangan) menjadi faktor yang dominan berpengaruh terhadap variabel minat berkunjung kembali ke wisata kota Bogor, hal tersebut disebabkan bahwa sub variabel hedonic (kesenangan) mempunyai nilai $t_{\text {hitung }}$ paling tinggi dan nilai probabilitasnya lebih kecil dari nilai probabilitas standar. Semakin kecil nilai probabilitas yang didapat maka semakin signifikan pengaruhnya terhadap minat untuk berkunjung kembali pada destinasi wisata kota Bogor. Sedangkan sub variabel education (edukasi) memiliki nilai negatif yang artinya education (edukasi) tidak mempunyai berpengaruh terhadap minat berkunjung kembali ke destinasi pariwisata kota Bogor, karena memiliki nilai thitung paling kecil dan kurang dari nilai tabel. Hal ini karena wisatawan yang datang ke destinasi pariwisata

Analisis Pengaruh Customer Experience Terhadap Minat Berkunjung Kembali (Revisit Intention)| 19 
kota Bogor berniat untuk berkunjung hanya untuk bermain dan berekreasi saja dan untuk edukasi telah didapatkan saat pertama kali berkunjung sehingga untuk kunjungan yang kedua kalinya wisatawan lebih memilih untuk bermain dan berekreasi.

\section{KESIMPULAN DAN IMPLIKASI}

Berdasarkan hasil dari penelitian, maka pembahasan mengenai analisis pengaruh dari customer experience terhadap minat berkunjung kembali (revisit intention) ke destinasi wisata kota Bogor diperoleh kesimpulan :

1. Gambaran mengenai customer experience pada destinasi wisata kota Bogor adalah :

a) Gambaran wisatawan terhadap variabel comfort/kenyamanan pada indikator lokasi bersih memiliki penilaian paling tinggi, sedangkan indikator menciptakan perasaan tenang dan tentram memiliki penilaian yang paling rendah.

b) Gambaran wisatawan terhadap variabel educational/edukasi pada indikator karyawan memiliki pengetahuann memperoleh penilaian yang paling tinggi, sedangkan indikator menciptakan kreativitas memiliki penilaian yang paling rendah.

c) Gambaran wisatawan terhadap variabel hedonic/kesenangan pada indikator mudah dikenang memiliki penilaian paling tinggi, sedangkan indikator menimbulkan kepuasan jasmani dan rohani memiliki penilaian yang paling rendah.

d) Gambaran wisatawan terhadap variabel novelty/kebaruan pada indikator mendapatkan petualangan baru memiliki penilaian paling tinggi, sedangkan indikator mendapatkan sensasi baru memiliki penilaian paling rendah. e) Gambaran wisatawan terhadap variabel safety/keamanan pada indikator memberi rasa kondusif memiliki penilaian paling tinggi, sedangkan indikator tidak membahayakan jiwa memiliki penilaian yang paling rendah.

f) Gambaran wisatawan terhadap variabel beauty/keindahan pada indikator keindahan alam wisata memiliki penilaian paling tinggi, sedangkan indikator menarik untuk di pandang memiliki penilaian yang paling rendah.

2. Secara simultan variabel comfort, education, hedonic, novelty, safety dan beauty berpengaruh positif dan juga signifikan terhadap minat berkunjung kembali pada destinasi wisata Kota Bogor.

3. Hasil pengujian secara parsial (uji-t) menyimpulkan bahwa faktor comfort, hedonic, novelty, safety dan beauty berpengaruh langsung, positif dan juga signifikan terhadap minat berkunjung kembali, sedangkan untuk faktor education tidak berpengaruh.

Berdasarkan kesimpulan di atas, maka untuk meningkatkan minat berkunjung kembali (revisit intention) pada destinasi wisata kota Bogor maka implikasi yang dapat disampaikan, adalah : bahwa faktor-faktor comfort, educational, hedonic, novelty, safety dan beauty perlu dipertahankan dan ditingkat , hal ini tidak terlepas dari kenyataan bahwa para wisatawan masa kini semakin berpengetahuan dan berpengalaman dan banyaknya tawaran-tawaran produk wisata yang semakin menarik dari berbagai destinasi wisata lain, sehingga hal ini menuntut para pengelola destinasi wisata untuk meningkatkan dan mempertahankan faktorfaktot tersebut diatas dengan cara meningkatkan kualitas dan mutu produk dan kualitas prasarana pendukung, menciptakan inovasi produk wisata yang berbeda sehingga menstimulus minat untuk berkunjung kembali dari para wisatawan. 


\section{UCAPAN TERIMA KASIH}

Mengucapkan terimakasih kepada pengunjung destinasi pariwisata kota Bogor khususnya para wisatawan Kebun Raya, The Jungle Waterpark, The Jungle Fest dan Marcopolo.

\section{DAFTAR PUSTAKA}

Alma, Buchari. 2001. Manajemen Pemasaran. Cetaka Keenam. Bandung : Alfabeta. 2004.Manajemen Pemasaran. Bandung : Alfabeta. 2016. Pemasaran Jasa .Cetakan Kedua belas. Bandung : Alfabeta.

Frankel, J dan Wallen, N 1993. How to Design and Evaluate Research in Education (2nd ed). Newyork : Mc. Graw-hill inc.

Fandy, Tjiptono, 2009. Strategi Pemasaran Jasa. Yogyakarta : CV Andi.

Gay, LR dan P.L Diehl 1992, Research Methods for Business Research Methods. Boston : Richard D.Irwin, Inc.

Ghozali, Imam. 2005. Aplikasi Analisis Multivariate dengan Program SPSS. Semarang : Badan Penerbit Universitas Diponegoro.

Hasan, Ali, 2015. Tourism Marketing. Yogyakarta : CAPS (Center for Academic Publishing Service).

Husein, Umar. 2003. Metode Riset Bisnis. Jakarta : Gramedia Pustaka Utama.

Kementrian Pariwisata Republik Indonesia. 2016. Data Pariwisata Nusantara. Jakarta : Kemenpar 2016.

Kompas, 2016. Peringkat Daya Saing Indonesia. 12 Juni 2016. Bogor.

Kotler, Heyes, Thomas, Bloom Paul N, (2002),Principles of marketing. Prentice Hall International, Inc.
Keler. 2007. Manajemen Pemasaran 1. Edisi Kedua Belas. Jakarta: PT. Indeks. . 2009. Manajemen Pemasaran Jilid 1. Edisi Ketiga Belas. Jakarta: Erlangga.

Kuo, Chen - Tsai. (2011).Tourist Satisfaction and Intention To Revisit Sun Moon Lake)

Lin, C.H. 2012.

Effect of Cuisine Experience, Psychologikal Well-Being, And Self-Health Perception on The Revisit Intention of Hot Springs Tourist Journal of Hospitality \& Tourism Research, p. 1-22.

Lupiyoadi, Rambat. 2014. Manajemen Pemasaran Jasa, Jakarta : Salemba Empat.

M. Manulang.2004. Dasar-Dasar Manajemen. Yogyakarta : Gajah Mada University Pres .

Meyer and Schwager, 2007. Understanding Customer Experience. USA. Harvard Bussines Review 1-12.

Nasir, M. 2003. Metode Penelitian Jakarta : Ghalia Indonesia.

Nazir, Mohammad. 1983. Metode Penelitian. Jakarta : Ghalia Indonesia..

Oka A, Yoeti, 2008. Ekonomi Pariwisata : Introduksi, Informasi, dan Implementasi. Jakarta : Kompas.

Priyatno, Duwi. 2011. Buku Saku Analisis Statistika Data SPSS. Yogyakarta : Mediakom.

Rageh, Ahmed, T.C Melewar dan Arch Woodside. 2013.Using Netnography Research Method to Reveal the Underlying Dimension of the Costumer/TouristExperience. Qualitati ve Market Research: An International Journal Vol. 16 No. 2, pp. 126-149.

Ramli, Soehatman, 2010. Sistem Manajemen Keselamatan Dan Kesehatan Kerja OHSAS 18001. Jakarta: Dian Rakyat. 
Schmitt, Bernd, 1999. Experience Marketing : Concept, Frameworks, and Consumer insight.

Smith, Shaun \& Wheeler, Joe, (2002), Managing Customer Experience, Turning Customer Into Advocates, Prentice Hall.

Sianipar, (2008). Analisis Customer Experience Terhadap Kepuasan Konsumen Pada Amazon Sun Plaza Medan. Universitas Sumatera Utara. Medan.

Sugiyono, 2004.Statistik Untuk Penelitian. Bandung: CV Alfabeta. , 2009.Metode Penelitian Bisnis. Bandung : Alfabeta.

2008. Metode Penelitian Kuantitatif-Kualitatif dan R\&D. Bandung : Alfabeta. , 2013. Statistik Untuk Penelitian. Bandung : Alfabeta.

Sumarsono, Sonny, 2004. Metode Riset Sumber Daya Manusia. Yogyakarta: Graha Ilmu.

Sumarwan, U. 2011. Perilaku Konsumen Teori dan Penerapannya dalam Pemasaran. Bogor: PT. Pradnya Paramita.

Songshan (Sam) Huang dan Cathy H.C. Hsu. 2009.Effect of Travel Motivation, Past Experience, Precevied Constraint, and Atitude on Revisit Intention.

Sunyoto, Danang. 2009. Analisis Regresi dan Uji Hipotesis. Edisi Pertama. Yogyakarta : Media Pressindo.

Suwantoro, Gamal, 2004, Dasar-Dasar Pariwisata, Yogyakarta : Penerbit Andi.

Undang -Undang RI Nomor 10 Tahun 2009 mengenai pariwisata. Jakarta.: Kementrian Ekonomi dan Kreatif. Departemen Kebudayaan dan Pariwisata. 2009.

Walter, Ute, B. Edvardsson dan Asa Ostrom. 2010. Drivers of customers service Experience: a studi in the restaurant insdustri . Managing Service Quality Vol.20 No.3,pp.236-258

William, Christine, dan John Buswell, 2003,Service Quality in Leisure And Tourism.CABI Publishing, Chambridge.

Yuniawati, Finardi, (2016). Pengaruh Customer Experience Terhadap Revisit Intention Di Taman Wisata Tangkuban Parahu. Universitas Pendidikan Bandung.

Zeithaml, V.A M.J Binter dan Gremler. 2009. Services Marketing: Integrating Customer Focus Across the Firm, 15th edition. New York : McGraw Hill 